\title{
LEO STRAUSS ON MACHIAVELLI: ATHENS VS. JERUSALEM OR ONTOLOGICAL ASSUMPTIONS ABOUT HUMAN NATURE AND POWER
}

\begin{abstract}
In this article we focus on the true nature of a disparity asserted in Leo Strauss's discussion of Machiavelli to amount to a virtue battle of sorts between Athens and Jerusalem. To convey this conflict Strauss is drawing both on his once Talmudic scholarship and his expertise in the history of political philosophy. We explore the stunning distortions, both theological and philosophical, in Strauss's discussion that appears aimed to support a conservative position on leadership, which calls for the magnanimous few to exercise power over the many (the lowborn, the poor and the vulgar). Not only does Strauss distort the interpretation of the Torah with respect to Isaiah, but he also does the same for the whole sequence of important figures in the history of philosophy: Kant, Marx, Spinoza, the Sophists, and Socrates. In the end we put in question whether there really is a meaningful contrast to be drawn between Athens and Jerusalem, and we suggest that the entire exercise by Strauss in his essay on Machiavelli is mostly an opportunity to espouse some extremist, or hard line Nietzschean views.
\end{abstract}

Key words: virtue, political power, magnanimity, shame, leadership, human nature

Leo Strauss introduces his essay about Machiavelli by opposing Athens and Jerusalem, asking the question "who is right?" about the conception of virtue. ${ }^{1}$ Aristotle, Strauss writes, describes a virtue "of first order called magnanimitythe habit of claiming high honors for oneself with the understanding that one is worthy of them." 2 This is contrasted to shame as a virtue, which Strauss argues is vindicated by the prophet Isaiah: "I am a man of unclean lips amidst a people of unclean lips."

A contradiction in views about the perception of one's own worth, and whether it is virtuous that it is held in high regard (such as in the Aristotelian

1 Leo Strauss, "Niccolo Machiavelli," in Leo Strauss and Joseph Cropsay eds. History of Political Philosophy ( $3^{\text {rd }}$ ed., Chicago: University of Chicago Press, 1987), p. 296. 
conception), or whether virtue commands that it be held in low regard (such as in the biblical conception), sets the stage for the esoteric exegesis of Machiavelli's Prince, and Discourses.

The question never receives explicit resolution, but we will argue that it does, resoundingly so, all things considered. For Strauss's argument is that Machiavelli presents a new bible, an anti-bible. ${ }^{3}$ One which sets a course for man-though not just any man - to lead, but which contrary to Machiavelli's contention, is not new but simply constitutes a re-appropriation of classical political philosophy. ${ }^{4}$ And hence, magnanimity wins the day, both for Machiavelli, and apparently for Strauss himself. Score one for Athens, then, (as well as Florence.)

But Jerusalem-as well as shame-will have a role to play in Machiavelli's "anti-bible"; that role, however, will be consistent more with a Greek conception of governance, as seen by Strauss, than with anything else. Jerusalem will be reserved for lesser men, in the interests of the regime.

\section{Magnanimity in Aristotle and Isaiah in Judaism: From Discrepancy to Consistency}

As a preliminary matter, it is worth investigating the tension Strauss establishes between the virtue of magnanimity, in the conception attributed to Aristotle, and the virtue of shame, which he attributes to the Judeo-Christian prophet Isaiah. First, does Aristotle really conceive of magnanimity as "the habit of claiming high honors for oneself with the understanding that one is worthy of them?" Secondly, is the conclusion to be drawn from Isaiah's expression, from a Judaic standpoint (and Strauss positions it as such by contrasting the "Greeks" and the "Jews") that shame is a virtue? We will argue that neither interpretation can stand, but that the contrast drawn by Strauss remains valid, though perhaps not in the terms he explicitly announces.

\section{Magnanimity}

In Book IV, Chapter 3 of the Nichomachean Ethics, ${ }^{6}$ Aristotle views magnanimity as "a sort of adornment of the moral virtues; for it makes them greater, and it does not arise without them." (1124a). There is no mention of claiming for oneself anything, let alone claiming honors for oneself, with whatever accompanying understanding. Furthermore, honor, in Aristotle's view, is not connected to magnanimity, but is a certain lesser nameless virtue which has to do with a range of desires for honor dealt with at 1125 b 1-4; namely, honor is something which "may be desired more than is right, or less, or from the right sources and in the right way" (1125 b 6-8). Aristotle does not relate

3 Ibid., p. 308.

$4 \quad$ Ibid., p. 306.

5 Ibid. p. 296.

6 Aristotle, Nicomachean Ethics, trans. Martin Ostwald (New York: Macmillan, 1962). 
magnanimity to a range of feeling (as he does with honor). Magnanimity is not a mean between two excesses with respect to the honor or honors claimed. Contrary to Strauss's claim, Aristotle actually recognizes that the interest of the great man in honors is a vanishing quantity. In fact Aristotle says that honor is the telos of "political life" (1095 b 23); that (ordinary) men pursue honor "in order to convince themselves of their own virtue" (1095 b 26-8; 1159 a 17-25), and they want to be honored for virtue by men endowed with practical wisdom (1095 b 28-9). But the great man, because he knows that he has complete virtue, requires no such honoring. He cares more for the good opinion of one good man than for any popular acclaim. What is more, he harbors contempt for casual crowd (1232 b 11-12). Aristotle distinguishes between two kinds of honor: the great and the small. The former is the good opinion which one good and wise man has of another; the latter is the tribute foolishly rendered by "the many" to power and wealth even when disassociated from virtue (1232 b 17-9).

Clearly Strauss' idea of "claiming" high honors for oneself-much less making a habit of it-is in reality antithetical to Aristotle's conception of a "great honor," which requires mutual recognition between equals who have achieved goodness and wisdom respectively.

\section{Shame}

As for Isaiah's expression of shame, it is no more supported by scholarly interpretation of the Torah, than is Strauss' conclusion with respect to Aristotle's view of magnanimity. Midrash (interpretation of the Bible) imagines an addition to the passage wherein God responds to Isaiah: "Of your own self you may say, 'I am a man of unclean lips.' That I will abide. But how dare you say 'I live among a people of unclean lips'?” (Song of Songs Rabbah, 1:38; see also Tanchuma Vayishlach 2). The Talmud has even interpreted Isaiah's gruesome death as punishment for his statement about his people. (Yevamot 39b) This has been understood as an ethical caution against stereotyping groups (Telushkin), ${ }^{7}$ and, more germane to a discussion regarding Machiavelli, a lesson about leadership. Indeed, a typical account from Conservative Judaism holds that "Isaiah's initiation as a prophet, according to this Midrash, was more than a divine ritual to inspire adequacy in the prophetic initiate. It was also a profound lesson in leadership." ${ }^{8}$ Here, perhaps, is where we can locate Strauss's potential standoff between Athens and Jerusalem: contrary to Aristotle (in The Politics, this time), rabbinical interpretation considers it necessary to assert strengths and not demean the people if one is to lead them. Hence: "Until Isaiah was able to acknowledge the strengths of his people rather than their weaknesses, the rabbis felt that he would be inadequate to his role as a prophet. This Midrash asserts that the commitment of the people to God and the Torah made them special its People, and its History. (New York: William Morrow, 1991), p. 450.

8 Conservative Yeshiva in Jerusalem, Haftarah, 2002, http://www.uscj.org/israelcenter/ haftarahEdit.php?id=64. 
despite any inadequacies that they might have. Any one who aspires to Jewish leadership must build on these virtues rather than on any perceived flaws if they truly desire to lead the community"'

Just as Strauss asks the rhetorical question about whether Machiavelli could have known that the number 26-of special importance in the structure of Machiavelli's works, according to Strauss-corresponds to the Hebrew letters for God, (and it does) so may it be asked, or even assumed, that Strauss, once the Talmudic scholar, was aware of the standard Jewish interpretation of Isaiah's expression, not as one of shame (as has been interpreted in Christian theology), but of highly inappropriate disregard for his own people. That would, however, in Strauss's defense, constitute a contrast to the Aristotelian view of both human nature, and the natural order of people, some of whom do, in Aristotle's view, certainly deserve to be the object of disdain. "The low-born, the poor, and the vulgar." ${ }^{10}$ It is thus in the ontological conception of human nature that Jerusalem and Athens draw their battle lines.

\section{Enlisted in Proxy Wars}

Strauss, however, also introduces others in this proxy war, including Kant, to whom Strauss attributes the idea "against the traditional view according to which a just society is one in which just men rule"-whose view and to what extent traditional is unclear-that "the problem of establishing the state is soluble even for a nation of devils, provided they have sense," to which Strauss adds, "provided they are shrewd calculators." 11 Does anything in this passagenot footnoted and apparently translated by Strauss himself, as no comparable translation exists in the English language-support this interpretation? We favor Lewis White Beck's English translation of Kant's Perpetual Peace, which at this place reads as follows: "The problem of organizing a state, however hard it may seem, can be solved even for a race of devils, if only they are intelligent." 12 However, regardless of what may be the best translation, what is important for us, though it may appear to be a quibble, is the distinction between Kant's formulation about devils in terms of the phrase "if only they are intelligent" and Strauss' rendition in terms of "provided that they are shrewd calculators", the latter seems somewhat as a slander, for Kant is famously not a utilitarian. ${ }^{13}$

$9 \quad$ Ibid.

10 Aristotle, Politics. Translated and edited by Ernest Barker. (Oxford: Oxford University Press, 1958): $1317 \mathrm{a} 22$.

11 Leo Strauss, "Niccolo Machiavelli," note 1, p. 298.

12 Immanuel Kant, On History, edited, with an introduction, by Lewis White Beck (New York, The Bobbs-Merrill co., 1963): p. 112.

13 The text immediately following Kant's statement about "a race of devils" being able to solve a problem of setting up a state makes it clear that this not dependent od "shrewd calculation": "The problem is: "Given a multitude of rational beings requiring universal laws for their preservation, but each of whom is secretly inclined to exempt himself from them, to establish a constitution in such a way that, although their private intentions conflict, they check each 
Strauss' excerpted passage is sufficiently similar to Kant's Perpetual Peace, that it can be concluded that it is drawn from the First Supplement, Article 1. But Kant speaks of "intelligence" and not of "sense," and he nowhere suggests that the "devils" in question are in any way "shrewd calculators." The emphasis in Perpetual Peace is on the establishment of peaceful international relations (as the title suggests), and secondarily on conditions, including domestic ones, that may bring about greater assurances of international peace. Of interest to Kant was a republic with separation of powers, as he argued that this model would insure checks against intemperate recourse to war. But Strauss concludes that Kant's claim is reflected in Marx, "for the proletarians from whom he expects so much are surely not angels." ${ }^{14}$ Not surprising, as the proletariat is none other than the vulgar, the lowborn and the poor, as far as Athens, and Strauss are concerned. That Marx had no interest whatsoever in the type of republic that Kant had in mind - the dictatorship of the proletariat hardly envisages a liberal democratic separation of powers-appears irrelevant to the thesis.

Next up is Spinoza, described improbably as Machiavelli's "pupil”, from whose work another claim without footnotes appears, namely that "justice rules only where just men rule." It should be noted that Kant has been, mere paragraphs earlier, said to have broken with a "traditional view" expressed in identical terms. ${ }^{15}$ But can this claim really be attributed to Spinoza? When understood in Strauss's context, it should be understood that it is just men who are the source of justice. Yet Spinoza speaks, if indeed this is what Strauss had in mind in the passage Strauss seems to have translated himself, of divine rule only being accessible through the rule of men, and reason, in the rule of law. ${ }^{16}$ First, Kant, if he strays from Spinoza, cannot be said to have strayed too far; secondly, how this could possibly be connected to Machiavelli is a mystery. It is critical to note, however, the extent to which Baruch Spinoza's political philosophy constitutes a break with (Jewish) religious tradition, claiming as it does that religious virtue-love, the good and justice-is to be established by the people, and in their governing institutions.

This is perhaps where Strauss sees the connection between Spinoza and Machiavelli, as the argument is developed that Machiavelli has blasphemed in ways so clever that only initiates can follow, and that in following, they, too, have become accomplices in his heresy. ${ }^{17}$ Thus, in the founding of this new Machiavellian order, justice is injustice, and fear replaces love. ${ }^{18}$ Yet none of this is new, as the ancients had already set it out, most likely first by Plato himself (the argument of Trasymachus in The Republic comes to mind).

other, with the result that their public conduct is the same as if they had no such intentions." Ibid, p. 112.

14 Leo Strauss, "Niccolo Machiavelli," p. 298.

15 Ibid. p. 298

16 Baruch Spinoza, Theological-Political Treatise. (Cambridge: Cambridge University Press, 2007): 19:33-19: 35.

17 Leo Strauss, "Niccolo Machiavelli," p. 312.

18 Ibid. p. 310. 
Religion is still required, at least in a Republic, ${ }^{19}$ even though according to Strauss, Machiavelli has rendered it obsolete (as it had been in Greece.) It is necessary for the demos, those who would rather see their fathers killed than their property seized, for it is they who better served by shame, while their magnanimous leaders claim the honors they know they deserve.

\section{Resolution: Enter (Covertly) Nietzsche and Heidegger}

To what ends are Spinoza, Kant, Aristotle, and Isaiah conscripted by Strauss in his reflections on Machiavelli, and in what direction are the various distortions pointing?

The essential question is first posed by Strauss as follows: Does Isaiah's "Jewish shame" or Aristotle's "magnanimity" prevail as a virtue? The question is then reframed as Athens against Jerusalem, but what if it is examined looking at matters in their correct context? Let us assume that the story of Isaiah has nothing to do with Jewish shame (and that this is in fact a Christian interpretation, while on the contrary, Judaic midrash has Isaiah's statement standing for the proposition that it is not ethical to stereotype people, or that much akin to Kant's deontology, it is not permitted to speak for others in confessing guilt; a moral agent is responsible solely for her own actions) and further, that as demonstrated, Aristotle never considered "magnanimity" as honor to be taken for oneself, knowing that one is worthy. If, then, the esoteric truth prevails (since Strauss has hidden the obvious meaning of the Judaic as well as the Aristotelian claim) what is opposed is God's commandment to lead (politically) only when assuming the virtues of one's people (Jerusalem), and earning (not claiming as one's own) respect (Athens)? Both claims become similarly virtuous, they both mean that respect is earned, and both conceive of others (and oneself) as an end, and never as a means.

There can then be no opposition between Athens and Jerusalem, in both cases, leadership is earned, not claimed, and ends are pursued for their own sakes. The idea of acting as if one's own people is virtuous (even if it is not) when entering onto a social contract (a covenant with God) may well seem like too dangerous a proposition, leading directly to Spinoza, Kant, and then, as Strauss would have it to Marx. Yet this is the lesson of Isaiah: in Judaism, shame was never the lesson.

If, however, the opposition is preserved, as Strauss sets it out, Jerusalem is shameful while Athens can claim high honors for itself, knowing that it is worthy. Upon what epistemic basis do these two claims rest? Why would Jerusalem think itself shameful (and this presumably be a virtue) while Athens would be so pleased with itself (and presumably rightly so) that it could collect its own honors, knowing it is worthy (and that this be also a virtue)? In other words, who decides this? In the case of Isaiah, it is not so difficult: he is speaking to God. Judaic interpretation has however never claimed that God in any way

19 Ibid. p. 314 
approved of Isaiah's statement; he may himself have had unclean lips (yet God called him as a prophet nonetheless), but he was not entitled to state that about others. The Greeks, in contrast, decide for themselves, and they, after all, created their gods in their own image.

If magnanimity, as recast by Strauss, is reflected in Machiavelli, it also means creating God in one's own image; this is the significance of chapter 26 of his discourses, Strauss argues; Machiavelli has replaced God with man (the Prince, or his advisor?) and this is the essence of his blasphemy. On the other hand, Isaiah and the Jews learn shame by being inferior before God. Jews do not kill God, but, in fact, it is the unspeakable Hebrew name of God (YHWH), which Strauss interprets esoterically to be the key to Machiavelli's choice of Chapter 26 to introduce man's victory over God. The tetragrammon, the name of God, when converted in numeric value in Hebrew, equals 26. And that is how Strauss sees Machiavelli triumphing over God, much as the Greeks had, as gods were created in their image. This is partially why Strauss can conclude that there was nothing new in Machiavelli; that the ancients had written all of it already.

And what of shame? Strauss may be suggesting that the Jewish people live as slaves before a God who reviles them; he would certainly not be the first to have defended such a view. What is interesting, however, is that one who did defend such a position, and who also considered that the ancients had created gods in their own image was Nietzsche, who plainly contrasted the Jews and the ancients, and in Beyond Good and Evil, made Jews responsible for the same decadent erosion of virtue leading to liberal degeneracy as characterizes much of Strauss's work. Slave morality, he wrote, was the province of the Jewish resentiment against their oppression; their ability to overcome oppression had led to ideas that destroyed ancient virtue, and perhaps magnanimity, as Strauss understood it. Strauss may have criticized Nietzsche, but his critique is hailed by some as having "revealed" the true Nietzsche.

What is "magnanimity" as redefined by Strauss if not Nietzsche's "noble man?"

The noble type of man regards himself as a determiner of values; he does not require to be approved of; he passes the judgment: „What is injurious to me is injurious in itself;" he knows that it is he himself only who confers honor on things; he is a creator of values. ${ }^{20}$

And what of Nietzsche's slave morality, the creation of which is explicitly attributed to Jews:

...the Jews achieved that miracle of inversion of values thanks to which life on earth has for a couple millennia acquired a new and dangerous fascinationtheir prophets fused 'rich, ' godless,' 'evil,' 'violent,' 'sensual' into one and were the first to coin the word 'world' as a term of infamy. It is this inversion of values (with which is involved the employment of the word for 'poor' as a synonym for 'holy' and 'friend') that the significance of the Jewish people resides: with them there begins the slave revolt in morals. ${ }^{21}$

20 Fredrich Nietzsche, Beyond Good and Evil, Beyond Good and Evil, tr. Kaufmann (New York, Penguin Random House, 1966), p. 195 (on slave morality).

21 Friedrich Nietzsche, Beyond Good and Evil, tr. Kaufmann (New York, 1966), p. 195 
Yet Nietzsche sees Jews not as inhabited by shame, but as shameless. What explains Strauss's description of Jewish shame as virtue, as erroneously concluded-at least from a Judaic perspective-from the passage regarding Isaiah's statement? Nietzsche has Jews triumph over their masters in the end, but the result is an inversion, and ultimately perversion, of morals. Strauss ignores the strong communitarian message emphasized by Midrash and Talmudic interpretation in Isaiah's intemperate statement about his coreligionists, which communitarian instinct-at the expense of the individual-is an aspect of Nietzsche's critique of Judaism. ${ }^{22}$ Heidegger, who was also a proponent of Athens, ${ }^{23}$ added: "Bolshevism is in fact Jewish." ${ }^{24}$ Are Jerusalem and Athens in fact opposed on the issue of who rules, and by virtue of what authority, rather than opposed on what seems like a rather tangential notion of whether shame, or magnanimity should prevail?

\section{About the Politics of Jerusalem and Athens}

By "who should rule," we mean to ask the question about whether leadership is reserved to some, or to all. Whose shame is it that in the Jerusalem account, God calls a man of unclean lips to become a prophet, and punishes him for stating that his people, too, have unclean lips? The fact is that Isaiah has not established any particular claim to honor. His people may not be entitled to claim it either. Yet, as the first contract theorists, the Jews have a covenant with God, and if one thinks that only noble men, or the well-born capable of virtue and practical wisdom should rule, that could seem like an inversion of moral values that they be given honors (Nietzsche), or it could support a blasphemy quite like that which Strauss believes Machiavelli to have committed. Jerusalem is not the quality of shame, but of Nietzschian "shamelessness," of collective political potential; Jerusalem is Spinoza, Kant, and Marx, it is what symbolizes the ascent of slaves to power, through revealed divine grant of reason, moral agency, and general laws.

In "Jerusalem," God issues commandments-unlike the man-made rules that Strauss calls Machiavelli's "new Decalogue"-to Moses, and justice will be considered just if it is applied equally, not, as in Athens, when applied equally among equals and unequally among non-equals. Nothing in these laws, establishing a divine social contract, will prohibit this people recently released from slavery to rule. How can this reflect a paradigmatic shame?

In "Athens," magnanimity, virtue, and practical knowledge are preferred qualities for rulers. Who decides? Men, not gods. Men, endowed of reason by nature, organize their polis, according to ways most suitable to its nature; they do

22 Friedrich Nietzsche, On the Genealogy of Morals, (Oxford, Oxford University Press, 2009).

23 Suzanne Marchand, "Review, Heidegger's Roots: Nietzsche, National Socialism, and the Greeks," Central European History 38 (2005): pp. 158-160.

24 See: Karl Jaspers, Philosophische Autobiographie (Munich: Piper, 1984), p 101; also Charles Bambach, Heidegger's Roots: Nietzsche, National Socialism, and the Greeks. (Ithaca: Cornell UP, 2003), p. 53. 
not include slaves, and seek to exclude the vulgar and low-born from influence in their political enterprise.

Strauss concludes his essay emphasizing the importance of the conflict between the Sophists and Socrates, leaving his reader to wonder, first, what happened to his initial framing question, regarding the virtue battle between Jerusalem and Athens, and secondly, what became of Aristotle, first introduced as the author of the concept of magnanimity?

\section{Sophists versus Socrates}

If the Sophists and Socrates are stand-ins for Jerusalem and Athens, then one would assume that the Sophists represent the Jews, and Socrates represents Athens. Strauss concludes that Machiavelli joins Socrates, as the two have shown that they could be feared, against the Sophists, whose mere reliance on speech could not suffice to discipline troops. Machiavelli and Socrates have power over God; while the Jews and Sophists are in the thrall of the word.

Yet Socrates, in the Meno, demonstrates that a slave can, through dialogue, overcome the most complex mathematical problem of the time. Thus Socrates relies on the word, not on "magnanimity" or the ability to be feared, to intellectually elevate a slave. And though this was not the crime for which Socrates was arrested, it could well represent a corruption of Aristotle's conception of nature, in which some are meant to be slaves. So, too, do the former slaves of Egypt, the Jews, enter into a covenant with God, through dialogue.

Strauss concludes that magnanimity has prevailed over shame, yet shame is non-existent throughout. "Shame" seems projected from above onto a conception of politics-whether Kant's, Spinoza's, Marx's, or that of the Decalogue-that would find virtue in a whole people, however imperfect. A shameless slave morality that is called shame fails when pitted against "magnanimity," an odd virtue that claims honor for oneself.

In the eyes of Machiavelli, Athens might well have prevailed. It is less certain, however, that Socrates would not be closer to the slaves than he was to the "magnanimous," for wasn't he capable of bringing a slave "out of Egypt" in defiance of convention? If Jews do not promote shame as a virtue, what did they promote? The respect of nomoi, established by a God that Spinoza would have said was of their own creation.

Jerusalem proclaims justice for all; the rulers and the ruled, and imposes one morality, one law, and one God: ${ }^{25}$ and those two central concepts, equality, and a single morality, explain how Strauss enlists Kant, whose Perpetual Peace attempts to organize a democratic system based on these ideas, removing them from the province of religion and morality into a real social order, as Spinozawho saw justice ${ }^{26}$ and charity as the essence of Judaic law, but only realized in

25 Grant Havers, "Between Athens and Jerusalem: Western Otherness in the Thought of Leo Strauss and Hannah Arendt," The European Legacy 9, (2004), p. 29.

26 Spinoza, Theological-Political Treatise: (16:73) Justice consists in the habitual rendering to every man his lawful due: injustice consists in depriving a man, under the pretence of 
the positive law $^{27}$-proposed. Thus, Strauss's claim that Kant's proposal that "even a race of devils"-even a people of unclean lips_can live justly in a just system is an idea that leads straight to Marx, can be understood. Surely, writes Strauss, Marx did not have angels in mind when thinking of the proletariat, and perhaps he did not; but all systems of government must envisage all the people to be governed, the difference lies only in how they are treated, the angels and the devils. Athens seeks to exclude those it does not find worthy; Jerusalem's "shame" is the "shamelessness" with which it applies justice to all. Isaiah returned to his people-and surely, as Strauss would say, they were not angels-with a message from God:

I the LORD have called thee in righteousness, and have taken hold of thy hand, and kept thee, and set thee for a covenant of the people, for a light of the nations; To open the blind eyes, to bring out the prisoners from the dungeon, and them that sit in darkness out of the prison-house. ${ }^{28}$

The foundational myth of Jerusalem is the opposite of shame; it is the embrace of all, under law, to open blind eyes, and to free the captives. Viewed as such, it is surely a radical message, and it stands in stark contrast to Athens' idea of nature. It is one that Plato and Machiavelli would surely have reviled, that much in Strauss's conclusion is true. But reducing the idea of general law, justice, and equality to shame can be said to be sophistry, and so, the Sophists stand with Plato, Xenophon, Machiavelli and Strauss. Socrates-who has Meno acknowledge that all men have the same conception of virtue and justice, ${ }^{29}$ would grant, we argue, an equal capacity of all men to govern if there were no slavery: ${ }^{30}$ his objection to Meno that not all men can govern is based on the empirical fact of slavery, one that is not rooted in an a priori about human nature, which Socrates demonstrates by showing that Meno's slave is perfectly capable of acquiring knowledge through reasoning that helps him recollect the forms. ${ }^{31}$ Thus, against the Sophists, Socrates and Jerusalem stand together.

legality, of what the laws, rightly interpreted, would allow him. (16:74) These last are also called equity and iniquity, because those who administer the laws are bound to show no respect of persons, but to account all men equal, and to defend every man's right equally, neither envying the rich nor despising the poor.

Ibid. 18:47; 19:12.

28 Isaiah 42:6-7, The Holy Scriptures, (Chicago: Jewish Publication Society, 1917).

29 Plato, The Meno (Plymouth, UK: Lexington Books, 2207): 73b.

30 Ibid, 73c,d.

31 Ibid, 85d 
